\title{
Short communication: Macrocyclic lactone residues in butter from Brazilian markets
}

\author{
Fabio Macedo, ${ }^{\dagger} \dagger$ Eliane Teixeira Marsico, ${ }^{*}$ Carlos Adam Conte-Júnior, ${ }^{*}$ Leonardo de Almeida Furtado, $\dagger$ \\ Taila Figueredo Brasil, $†$ and Annibal Duarte Pereira Netto ${ }^{1}$ \\ *Faculdade de Veterinária, Universidade Federal Fluminense, Rua Vital Brazil Filho, 64, Santa Rosa 24230-340, Niterói, RJ, Brazil \\ †Instituto de Química, Universidade Federal Fluminense, Outeiro de São João Batista, s/n, Valonguinho 24020-141, Niterói, RJ, Brazil
}

\begin{abstract}
Macrocyclic lactones (ML) are commonly used in drug formulations for the treatment of parasites in cattle. In Brazil, except for drugs (or formulations) with long-term (half-life) effects, ML are registered for use in bovines. Indiscriminate use of ML may result in the presence of residues in milk and dairy products due to their lipophilic properties and thermal stability. This study applied a method of liquid chromatography with fluorimetric detection, recently developed and validated for the determination of residues of abamectin, doramectin, ivermectin, and moxidectin in butter. The method was applied to 38 samples of commercial butter purchased in the metropolitan area of Rio de Janeiro, Brazil, between June and September 2013, analyzed in triplicate. Ivermectin was detected in $89.5 \%$ of the samples, with concentrations between 0.3 and $119.4 \mu \mathrm{g} / \mathrm{kg}$; $76.3 \%$ of the samples contained doramectin (0.6 to 64.7 $\mu \mathrm{g} / \mathrm{kg}$ ) and $55.2 \%$ contained abamectin (0.7 to $4.5 \mu \mathrm{g} /$ $\mathrm{kg})$. Most butter samples (76.3\%) contained residues of more than $1 \mathrm{ML}$; however, no residues of moxidectin were detected. The results showed a high incidence of the presence of avermectins in butter samples. Butter is not included in the Brazilian National Plan for Control of Residues and Contaminants in Animal Products. As ML residues concentrate in lipophilic compounds, butter and other fatty dairy products should be screened for the presence of ML residues.
\end{abstract}

Key words: macrocyclic lactone, veterinary drug residue, commercial butter, liquid chromatography

\section{Short Communication}

The occurrence of macrocyclic lactones (ML) in milk has been reported in several studies (Lobato et al., 2006; Danaher et al., 2012; Furlani et al., 2014). The

Received November 19, 2014.

Accepted March 4, 2015.

${ }^{1}$ Corresponding author: annibal@vm.uff.br avermectins abamectin (ABA), doramectin (DOR) and ivermectin (IVM), and the milbemycin moxidectin (MOX) are widely used as antiparasitic agents due to their endectocide properties at low doses (Souza et al., 2007). In Brazil, these compounds are registered for use in dairy cattle (SINDAN, 2014). Despite their benefits, these chemicals are only slowly eliminated from the body of cattle (Danaher et al., 2006) and the recommended withdrawal period must be obeyed. Their indiscriminate use in veterinary medicine may result in the presence of their residues in milk and milk-derived products (Furlani et al., 2014).

Dairy products are important sources of nutrients, especially proteins, minerals, and FA, essential for certain groups of consumers including children, women, and the elderly (Souza et al., 2011). Brazil is the main milk producer in South America and the fifth-largest producer worldwide (FAO, 2014). Small family farms occupying $24 \%$ of the rural area are responsible for $58 \%$ of the total milk production in Brazil (de França et al., 2009).

In Brazil, ML in milk is monitored under 2 different programs. One of them has been administered since 1986 by the Ministry of Agriculture, Livestock and Food Supply under the National Plan for Control of Residues and Contaminants in Animal Products. The other program, in effect since 2003, is administered by the Brazilian Ministry of Health, under the National Health Surveillance Agency (Brasil, 1986; 2003). According to the Ministry of Agriculture, Livestock and Food Supply, $100 \%$ of the 640 raw milk samples analyzed in the last $5 \mathrm{yr}$ were compliant, showing residues below the maximum residue limits (MRL) for ML in milks adopted in Brazil $(10 \mu \mathrm{g} / \mathrm{L}$ for ABA, IVM, and MOX, and $15 \mu \mathrm{g} / \mathrm{L}$ for DOR; Brasil, 2010; 2011; 2012; 2013; 2014a, b). According to the National Health Surveillance Agency, none of the 603 samples (powdered milk and UHT fluid milk) analyzed for ML showed ABA and IVM residues above their MRL, but 9 samples (1.49\%) showed DOR residues above its MRL. However, residues of DOR below its MRL were found in 91.3 and $100 \%$ of commercial samples of UHT and 
powdered milk, respectively, in samples from the city of Rio de Janeiro (Brasil, 2009). Some investigators (Lobato et al., 2006; Kolberg et al., 2009; Rübensam et al., 2011; Furlani et al., 2014) in chromatographic studies of the presence of ML residues in Brazilian milk samples found no samples of raw, pasteurized, or UHT milk with ML residues above the Brazilian MRL (Brasil, 2014b).

Conversely, studies of dairy products have shown that ML are stable under the common processing conditions of heating (Cerkvenik et al., 2001; Imperiale et al., 2009), lactic acid fermentation (Cerkvenik et al., 2004), and freezing at $-20^{\circ} \mathrm{C}$ (Cerkvenik et al., 2001). During cheese production, the highest residual concentrations of ML were measured in curd and were 3.0 to 4.0 fold higher in sheep and buffalo cheeses than in the corresponding milks (Anastasio et al., 2002; Imperiale et al., 2004). Although these studies demonstrated the potential presence of ML in dairy products, and a positive correlation with milkfat content (Cerkvenik et al., 2004), to the best of our knowledge no analytical methods capable of evaluating ML in butter have been published, except in our recent paper (Macedo et al., 2015).

Butter is a fatty product derived exclusively from milk, with a minimum milkfat content of $80 \%$ (Codex Alimentarius, 2010), which may concentrate lipophilic compounds. Therefore, butter may potentially concentrate the lipophilic ML and its monitoring is of interest, especially as it is an inexpensive and widely consumed food. The estimated annual per capita consumption of butter ranges from 0.103 to $0.410 \mathrm{~kg}$ in different regions of Brazil (IBGE, 2010).

The objective of the current study was to evaluate the occurrence of $4 \mathrm{ML}$ (ABA, DOR, IVM, and MOX) in butter sold in the metropolitan area of Rio de Janeiro. The samples consisted of packages containing $200 \mathrm{~g}$ of butter from 38 brands and different lots, of different origins, produced during May and June 2013. These samples were from different states in important producer regions: the southeast (Minas Gerais, Rio de Janeiro, São Paulo, and Espírito Santo) and south (Paraná and Santa Catarina). The samples were purchased in bakeries and supermarkets in the metropolitan area of Rio de Janeiro, Brazil. The samples were produced in processing plants under the Federal Inspection Service (SIF; 25 samples), under the Rio de Janeiro State Inspection Service (SIE; 6 samples), or the Espírito Santo State Inspection Service (1 sample). The samples were distributed as follows: Minas Gerais (17), Rio de Janeiro (10), Paraná (3), Espírito Santo (1), São Paulo (1), and Santa Catarina (1). One sample from Minas Gerais was a homemade product designated for personal consumption, and 5 samples were imported from Argentina (2),
France (2), and Italy (1). The samples were stored at 4 $\pm 2^{\circ} \mathrm{C}$ until analysis.

Solid standards of ABA, DOR, and MOX were purchased from Fluka (Steinheim, Baden-Württemberg, Germany) and of IVM from Sigma-Aldrich (St. Louis, MO). Standard stock solutions of the individual ML $(200 \mathrm{mg} / \mathrm{L})$ were prepared by dissolving $2 \mathrm{mg}$ of each standard in $10 \mathrm{~mL}$ of acetonitrile (ACN). A working standard solution of the selected compounds $(2 \mathrm{mg} / \mathrm{L})$ was prepared by diluting aliquots of each stock solution with ACN. The stock solutions were stored at $-20^{\circ} \mathrm{C}$ in the dark in amber glass flasks and discarded after 1 mo. These solutions were used to spike blank samples at different levels for calibration purposes. Both ACN and ethyl acetate (HPLC grade) were purchased from TediaBrazil (Rio de Janeiro, Brazil). The derivatization reagents triethylamine, trifluoroacetic anhydride, and trifluoroacetic acid were purchased from Sigma-Aldrich and 1-methylimidazole was purchased from Fluka. Ultrapure water was prepared in a Millipore Milli-Q system (Billerica, MA) following reverse osmosis (Rios DI-3, Millipore).

Samples were extracted and analyzed in independent triplicates using a procedure previously developed and validated by Macedo et al. (2015). Briefly, aliquots of $0.5 \mathrm{~g}$ of butter were heated to their melting point $\left(50^{\circ} \mathrm{C}\right)$, and $10 \mathrm{~mL}$ of a solution containing ACN, ethyl acetate, and water $(90: 4: 6, \mathrm{vol} / \mathrm{vol} / \mathrm{vol})$ was added at $50^{\circ} \mathrm{C}$. The resulting mixture was vortex-mixed for $30 \mathrm{~s}$ and placed for 2 min in a water bath $\left(50^{\circ} \mathrm{C}\right)$, mixed again, and ultrasonically extracted for $10 \mathrm{~min}$. The mixture was cooled to room temperature and centrifuged at $4.226 \times$ $g$ for 10 min at room temperature. The upper phase was removed and filtered through polytetrafluoroethylene filters $(0.45 \mu \mathrm{m}$, Agilent, Santa Clara, CA). The resulting solution was concentrated to $<500 \mu \mathrm{L}$ in a rotary evaporator at $60^{\circ} \mathrm{C}$ and finally concentrated to near dryness $(25 \mu \mathrm{L})$ under a gentle nitrogen flow.

Calibration standards were prepared as independent triplicates using matrix-matched calibration. Briefly, blank butters were spiked from 0.8 to $70.0 \mu \mathrm{g} / \mathrm{kg}$ and extracted and derivatized as described for the samples. Two different calibration ranges (a narrow range, from 0.8 to $6.0 \mu \mathrm{g} / \mathrm{kg}$, and a wider range, from 6.0 to $70.0 \mu \mathrm{g} / \mathrm{kg}$ ) were used, similar to the procedure of Cerkvenik-Flajs et al. (2010). The curve equations were adjusted by the least-squares method, using a linear model for the narrow range and a second-order model for the wider range of calibration, and used to determine the parameters of the calibration lines and the correlations between chromatographic peak areas and standard concentrations. This procedure was adopted because preliminary results showed that some samples contained concentrations of certain ML, especially IVM 
Table 1. Validation data for determination of macrocyclic lactones in butter by the optimized liquid chomatographic method ${ }^{1}$

\begin{tabular}{lcccccc}
\hline Analyte $^{2}$ & $\begin{array}{c}\text { Mean LOD } \\
(\mu \mathrm{g} / \mathrm{kg})\end{array}$ & $\begin{array}{c}\text { Mean LOQ } \\
(\mu \mathrm{g} / \mathrm{kg})\end{array}$ & $\begin{array}{c}\text { Overall CC } \\
(\mu \mathrm{g} / \mathrm{kg})\end{array}$ & $\begin{array}{c}\text { Overall CC } \\
(\mu \mathrm{g} / \mathrm{kg})\end{array}$ & $\begin{array}{c}\text { Overall precision } \\
(\mathrm{CV} \%)\end{array}$ & $\begin{array}{c}\text { Overall recovery } \\
(\%)\end{array}$ \\
\hline ABA & 0.04 & 0.12 & 0.14 & 0.17 & 10.86 & 80.50 \\
DOR & 0.05 & 0.15 & 0.22 & 0.28 & 10.40 & 76.20 \\
IVM & 0.05 & 0.16 & 0.18 & 0.25 & 12.06 & 12.63 \\
MOX & 0.03 & 0.09 & 0.13 & 0.17 & 72.90 \\
\hline
\end{tabular}

${ }^{1} \mathrm{LOD}=$ limit of detection; $\mathrm{LOQ}=$ limit of quantification; $\mathrm{CC}_{\alpha}=$ decision limit; $\mathrm{CC}_{\beta}=$ detection capability.

${ }^{2} \mathrm{ABA}=$ abamectin; $\mathrm{DOR}=$ doramectin $; \mathrm{IVM}=$ ivermectin; $\mathrm{MOX}=$ moxidectin.

and DOR, that significantly exceeded the narrow calibration range. A dilution step was omitted in order not to reduce the method throughput, because at least 6 determinations would be necessary for some samples because they were always analyzed in independent triplicates.

The detection of ML using fluorescence required a previous reaction to generate a fluorescent moiety, which was carried out as described by Berendsen et al. (2007). The concentrated extracts or appropriate aliquots of the standard solutions were derivatized after addition of $100 \mu \mathrm{L}$ of a mixture of methylimidazole:ACN (1:1, $\mathrm{vol} / \mathrm{vol}), 50 \mu \mathrm{L}$ of triethylamine, $150 \mu \mathrm{L}$ of a mixture of trifluoroacetic anhydride:ACN $(1: 2, \mathrm{vol} / \mathrm{vol})$, and 50 $\mu \mathrm{L}$ of trifluoroacetic acid, heated at $70^{\circ} \mathrm{C}$ for $30 \mathrm{~min}$, cooled to room temperature, and analyzed using HPLC with fluorescence detection (Macedo et al., 2015). The chromatographic system consisted of a vacuum degasser, quaternary pump, autosampler, column oven, and fluorescence detector (Agilent 1100 Series), and was controlled by an Agilent ChemStation. The ML were separated using a Waters SunFire C8 column (150 $\times 4.6 \mathrm{~mm}, 5 \mu \mathrm{m}$, Waters, Milford, MA) connected to a guard column $(12.5 \times 4.6 \mathrm{~mm}, 5 \mu \mathrm{m})$ with the same characteristics. A gradient of acetonitrile and water at a flow rate of $1.2 \mathrm{~mL} \mathrm{~min}{ }^{-1}$ allowed the separation of the ML derivatives. The gradient started at $88 \%$ acetonitrile with a linear increase up to $97 \%$ acetonitrile in 8 min, and was then held constant for 4.5 min for a total run time of $12.5 \mathrm{~min}$. An additional 5 -min period was necessary to reestablish the initial chromatographic conditions. The column temperature was $31^{\circ} \mathrm{C}$ and the injection volume was $20 \mu \mathrm{L}$. The excitation and emission wavelengths were 365 and $470 \mathrm{~nm}$ respectively. The solvents were degassed for $20 \mathrm{~min}$ in an ultrasonic bath before use.

Table 1 summarizes the main analytical figures of merit of the analytical method of ML determination (Macedo et al. 2015). The method showed satisfactory selectivity and high sensitivity for the evaluation of ML residues in butters at the levels commonly found in dairy products, with a precision evaluated by the coefficient of variation according to tolerances recom- mended in international guidelines (EC, 2002; Codex Alimentarius, 2009).

The narrow calibration range (from 0.8 to $6.0 \mu \mathrm{g} /$ $\mathrm{kg}$ ), which followed a linear model, was employed in the determination of the less-concentrated samples. The wide calibration range (from 6.0 to $70.0 \mu \mathrm{g} / \mathrm{kg}$ ), which led to a second-order model, was used to estimate the concentrations of IVM and DOR in the morecontaminated samples.

Calibration curves of individual derivatives obtained in the wide range showed excellent determination coefficients $(\geq 0.999)$, indicating good adherence to the second-order models shown in Table 2. To ensure the confidence of this mathematical treatment, 6 extracts of highly contaminated samples were diluted to the linear range initially proposed and were reanalyzed (Table 3 ). The concentrations found using both models were in good agreement, thus confirming the validity of using the second-order curve.

Even though MOX shows a high milk-to-plasma ratio and post-treatment persistence in plasma (Imperiale et al., 2004), none of the butters contained residues of this MOX. However, residues of the other $3 \mathrm{ML}$ (ABA, DOR, and IVM) were present in some butters (Table 4). The ABA residues were found in $44.7 \%$ of the samples; this was the least common ML found in the samples, except for MOX (Table 4). The concentrations of ABA ranged from 0.7 to $4.5 \mu \mathrm{g} / \mathrm{kg}$, the latter in a butter produced in Minas Gerais; the median concentration was $1.4 \mu \mathrm{g} / \mathrm{kg}$. Six of the 10 samples produced in Rio de Janeiro contained ABA (1.4-3.7 $\mu \mathrm{g} / \mathrm{kg}$; median = $2.2 \mu \mathrm{g} / \mathrm{kg})$. The residues of ABA occurred in a narrow range, and were lower than the levels found for DOR and IVM.

The DOR was detected in $76.3 \%$ of the butters at concentrations ranging from 0.6 to $64.7 \mu \mathrm{g} / \mathrm{kg}$, with the homemade sample from Minas Gerais showing the highest concentration among the studied samples. Even excluding this sample, $73.6 \%$ of the butters tested positive for contamination with DOR (0.6 to $35.8 \mu \mathrm{g} / \mathrm{kg}$ ). The level of butter contamination with DOR seems to be related not only to its long persistence in milk (Danaher et al., 2006), but also to the effectiveness of 
Table 2. Data for the calibration models of the proposed chromatographic method for determination of macrocyclic lactones in butter

\begin{tabular}{llll}
\hline Analyte $^{1}$ & $\begin{array}{l}\text { Concentration } \\
\text { range }(\mu \mathrm{g} / \mathrm{kg})\end{array}$ & Regression equation & \\
\hline ABA & $0.8-6.0$ & Peak area $=11.102 C-3.9416$ & $\mathrm{R}^{2}$ \\
& $6.0-70.0$ & Peak area $=-0.0104 C^{2}+10.013 C-0.4957$ & 0.999 \\
DOR & $0.8-70.0$ & Peak area $=-0.0111 C^{2}+10.071 C-1.3512$ & 0.999 \\
& $0.8-6.0$ & Peak area $=6.4762 C-0.0573$ & 0.999 \\
& $6.0-70.0$ & Peak area $=-0.0055 C^{2}+6.4351 C-0.4216$ & 0.998 \\
IVM & $0.8-70.0$ & Peak area $=-0.0052 C^{2}+6.4185 C-0.1974$ & 0.999 \\
& $0.8-6.0$ & Peak area $=8.6512 C+8.6627$ & 0.999 \\
MOX & $6.0-70.0$ & Peak area $=-0.0200 C^{2}+10.932 C-5.6124$ & 0.998 \\
& $0.8-70.0$ & Peak area $=-0.0111 C^{2}+10.164 C+1.563$ & 0.999 \\
& $0.8-6.0$ & Peak area $=10.844 C+9.9097$ & 0.999 \\
& $6.0-70.0$ & Peak area $=-0.0217 C^{2}+14.377 C-12.961$ & 0.998 \\
& $0.8-70.0$ & Peak area $=-0.0131 C^{2}+13.633 C-0.1866$ & 0.999 \\
\hline
\end{tabular}

${ }^{1} \mathrm{ABA}=$ abamectin; $\mathrm{DOR}=$ doramectin IVM $=$ ivermectin; MOX $=$ moxidectin.

${ }^{2} C=$ analyte concentration.

inspection procedures, because the highest levels $(2.6$ to $35.8 \mu \mathrm{g} / \mathrm{kg} ;$ median $=11.3 \mu \mathrm{g} / \mathrm{kg}$ ) were found in butters produced in plants monitored by SIE. Butters produced in Rio de Janeiro $(1.6-9.6 \mu \mathrm{g} / \mathrm{kg}$; median = $6.0 \mu \mathrm{g} / \mathrm{kg}$ ) and Minas Gerais $(0.6-11.2 \mu \mathrm{g} / \mathrm{kg}$; median $=3.8 \mu \mathrm{g} / \mathrm{kg})$ in processing plants under SIF showed similar levels of contamination and lower concentration ranges than those in plants monitored by SIE. These results could be explained by the official monitoring of the milk supplied by dairy farms to dairy processing plants monitored by SIF, which is regularly collected under the authority of the National Plan for Control of Residues and Contaminants in Animal Products (Brasil, 2014b) and analyzed for the presence of residues. Similarly, Spisso et al. (2010) found a higher proportion of positive samples for tetracyclines (a class of broadspectrum antimicrobials) in pasteurized milks from plants monitored by SIE than by SIF.

Ivermectin, the ML residue found most frequently in the butters $(89.5 \%)$, showed a similar trend. The highest level of contamination $(119.4 \mu \mathrm{g} / \mathrm{kg})$ was found in a sample produced in a plant monitored by the Rio de Janeiro SIE, whereas the lowest level $(0.3 \mu \mathrm{g} / \mathrm{kg})$ was found in a butter from Santa Catarina, under SIF inspection. The same trend was not observed in the imported brands. Except for 1 sample from Argentina that contained IVM at $1.1 \mu \mathrm{g} / \mathrm{kg}$, the imported samples were free of all $4 \mathrm{ML}$ investigated. However, this small number of samples is insufficient to determine the overall quality of imported butter and, consequently, of the butter produced in these countries.

All 33 Brazilian butters contained some level of IVM, regardless of their origins and federal (SIF) or state inspection (SIE). Twenty-nine of them contained DOR and 17 contained ABA. At least $87.8 \%$ of these samples contained more than $2 \mathrm{ML}$ and $51.5 \%$ contained all 3 avermectins.

These results confirm that IVM is the most frequently used ML in treating lactating cows in the regions of Brazil that provided the butter samples. The occurrence of high levels of IVM in butters may result from its widespread use in Brazil in beef cattle and dairy

Table 3. Agreement between the concentrations of macrocyclic lactones, estimated using the linear and second-order polynomial models for butter analyses

\begin{tabular}{|c|c|c|c|c|c|c|}
\hline Sample & Analyte $^{1}$ & $\begin{array}{l}\text { Second-order }{ }^{2} \\
(\mu \mathrm{g} / \mathrm{kg})\end{array}$ & $\begin{array}{l}\text { Linear }^{3} \\
(\mu \mathrm{g} / \mathrm{kg})\end{array}$ & $\begin{array}{l}\text { Dilution } \\
\text { factor }\end{array}$ & $\begin{array}{c}\text { Estimated } \\
\text { concentration }^{4} \\
(\mu \mathrm{g} / \mathrm{kg})\end{array}$ & $\begin{array}{l}\text { Agreement of values }{ }^{5} \\
\text { (linear/second-order; \%) }\end{array}$ \\
\hline 1 & DOR & 35.8 & 3.6 & 10 & 36 & 100.5 \\
\hline 2 & DOR & 64.7 & 6.5 & 10 & 65 & 100.4 \\
\hline 3 & IVM & 12.2 & 1.2 & 10 & 12 & 98.3 \\
\hline 4 & IVM & 23.6 & 2.3 & 10 & 23 & 97.4 \\
\hline 5 & IVM & 26.8 & 2.6 & 10 & 26 & 97.0 \\
\hline 6 & IVM & 40.9 & 4.1 & 10 & 41 & 100.2 \\
\hline
\end{tabular}

${ }^{1} \mathrm{DOR}=$ doramectin; IVM = ivermectin.

${ }^{2}$ Analyte concentration estimated using second-order polynomial model.

${ }^{3}$ Analyte concentration estimated by linear model, after dilution.

${ }^{4}$ Analyte concentration estimated by linear model $\times$ dilution factor.

${ }^{5}$ Ratio (concentration by linear model/concentration by second-order polynomial model) $\times 100$. 
Table 4. Occurrence and levels of residues of macrocyclic lactones found in butter samples

\begin{tabular}{|c|c|c|c|c|c|c|c|}
\hline \multirow[b]{2}{*}{$\mathrm{ML}^{1}$} & \multicolumn{2}{|c|}{$\begin{array}{l}\text { Macrocyclic lactone concentrations } \\
\qquad(\mu \mathrm{g} / \mathrm{kg})\end{array}$} & \multicolumn{5}{|c|}{ Contaminated samples (\%) } \\
\hline & Minimum & Maximum & Total & $\begin{array}{c}\mathrm{SIF}^{2} \\
(\mathrm{n}=25)\end{array}$ & $\begin{array}{c}\mathrm{SIE}^{3} \\
(\mathrm{n}=7)\end{array}$ & $\begin{array}{l}\mathrm{IMP}^{4} \\
(\mathrm{n}=5)\end{array}$ & $\begin{array}{c}\mathrm{HM}^{5} \\
(\mathrm{n}=1)\end{array}$ \\
\hline ABA & 0.7 & 4.5 & 44.7 & 52.0 & 57.1 & 0 & 0 \\
\hline DOR & 0.6 & 64.7 & 76.3 & 84.0 & 100.0 & 0 & 100.0 \\
\hline IVM & 0.3 & 119.4 & 89.5 & 100.0 & 100.0 & 20.0 & 100.0 \\
\hline
\end{tabular}

cows, because IVM is present in 76 of the 135 veterinary formulations containing at least 1 of the $4 \mathrm{ML}$ registered for use with cattle in Brazil (SINDAN, 2014).

Only a few studies have monitored ML in Brazilian milk (Lobato et al., 2006; Kolberg et al., 2009; Rübensam et al., 2011, Furlani et al., 2014), and all of them found ML residues below the Brazilian MRL (Brasil, 2014b). These results agree well with the latest results from the monitoring plans undertaken by the Brazilian authorities (Brasil, 2009, 2010, 2011, 2012, 2013, 2014a), which showed that milks were compliant (residues below the MRL). This consistent pattern of ML residues in milk suggests that consumers are not exposed to harmful levels of these residues by consuming milk produced in these regions of the country.

All Brazilian butters contained some level of ML. Due to the lipophilic characteristics of ML and the high fat content of butter ( $\geq 80 \% \mathrm{wt} / \mathrm{wt})$, these compounds would become concentrated in butter. Notwithstanding the different results found for milks and butters, our results showed that the butters evaluated contained at least 1 of the 4 ML analyzed. Extra-label use of ML in cattle does not seem to be a risk for milk processing (Cerkvenik et al., 2004), but can affect public health if these drug residues are present in milk and dairy products. The presence of ML residues in butter also implies that the mandated withdrawal period before milking may not always be observed, indicating a lack of compliance with good veterinary practices. Our data add to the knowledge of consumer exposure to ML in dairy products. The determination of ML residues in butter has proven to be essential to ensure food quality.

To the best of our knowledge, ours is the first published survey presenting data on ML in butters. Thirtythree Brazilian and 5 imported samples were evaluated. Residues of IVM were found in all Brazilian samples, and residues of DOR and ABA were found in 87.8 and
$51.5 \%$ of the Brazilian samples. Levels of ABA residues were lower than levels of residues of DOR and IVM; MOX was not found in any sample. All but 1 sample from the imported brands showed no ML residues. Our results confirm that IVM and DOR are the ML-class drugs that are most frequently used in dairy cows in Brazil. Considering that no MRL has been established for ML in butter, it is not possible to assess the percentage of noncompliant samples; however, the presence of residues in many samples indicates that good veterinary practices are not always followed. These results emphasize the importance of including butter, a high-fat dairy product, in official monitoring plans for lipophilic residues such as ML.

\section{ACKNOWLEDGMENTS}

The authors are grateful for financial support from the State of Rio de Janeiro Carlos Chagas Filho Research Foundation (FAPERJ) (process E-26/112.620/2012), and the Brazilian National Council for Scientific and Technological Development (CNPq)/Ministry of Agriculture, Livestock and Food Supply (MAPA) (process 578782/2008-1). Fabio Macedo thanks CAPES for a doctoral fellowship. Leonardo A. Furtado thanks PI$\mathrm{BIC} / \mathrm{CNPq}$ for an undergraduate grant. Taila F. Brasil thanks Federal Fluminense University for an undergraduate grant. Annibal D. Pereira Netto thanks CNPq for an individual research grant.

\section{REFERENCES}

Anastasio, A., M. Esposito, M. Amorena, P. Castellani, L. Serpe, and M. L. Cortesi. 2002. Residue study of ivermectin in plasma, milk, and mozzarella cheese following subcutaneous administration to buffalo (Bubalus bubalis). J. Agric. Food Chem. 50:5241-5245.

Berendsen, B. J., P. P. Mulder, and H. J. van Rhijn. 2007. The new derivatisation of avermectins and milbemycins in milk: new insights and improvement of the procedure. Anal. Chim. Acta $585: 126-133$. 
Brasil. 1986. Ministério da Agricultura. Portaria No. 51, de 06 de Maio de 1986. Dispõe sobre a instituição do Plano Nacional de Controle de Resíduos Biológicos em Produtos de Origem Animal - PNCRB. DOU Seção 1. 2288. Diário Oficial da União, Brasília, DF, Brazil. Accessed Jun. 12, 2014. http://sistemasweb.agricultura.gov.br/ sislegis/action/detalhaAto.do? method=gravarAtoPDF \& tipo $=\mathrm{PO}$ R\&numeroAto $=00000051 \&$ seqAto $=000 \&$ valor $A n o=1986 \&$ orgao $=$ MAPA\&codTipo $=\&$ desItem $=\&$ desItemFim $=$.

Brasil. 2003. Agência Nacional de Vigilância Sanitária. Resolução RDC No. 253 de 16 de Setembro de 2003. Cria o Programa Nacional de Análise de Resíduos de Medicamentos Veterinários em Alimentos de Origem Animal - PAMVet. DOU Seção 1. 181:9091. Diário Oficial da União, Brasília, DF, Brazil. Accessed Jul. 1, 2014. http://pesquisa.in.gov.br/imprensa/jsp/visualiza/index.jsp? data $=18 / 09 / 2003 \&$ jornal $=1 \&$ pagina $=90 \&$ totalArquivos $=256$.

Brasil. 2009. Agência Nacional de Vigilância Sanitária. Programa Nacional de Análise de Resíduos de Medicamentos Veterinários em Alimentos de Origem Animal - PAMVet. Relatório 2006-2007. Monitoramento de Resíduos em Leite Exposto ao Consumo $\left(5^{\circ} \mathrm{e}\right.$ $6^{\circ}$ anos de atividades). Brasília, DF, Brazil. Accessed Jul. 1, 2014. http://portal.anvisa.gov.br/wps/wcm/connect/72efdb0047458ad1 9441d43fbc4c6735/PAMVET.pdf?MOD=AJPERES.

Brasil. 2010. Ministério da Agricultura, Pecuária e Abastecimento. Instrução Normativa No. 06, de 16 de março de 2010. Diário Oficial da União, Brasília, DF, Brazil. Accessed Jul. 5, 2014. http://www. agricultura.gov.br/arq_editor/file/CRC/IN\%2006-2010.pdf.

Brasil. 2011. Ministério da Agricultura, Pecuária e Abastecimento. Instrução Normativa No. 06, de 25 de fevereiro de 2011. Diário Oficial da União, Brasília, DF, Brazil. Accessed Jul. 5, 2014. http:// www.agricultura.gov.br/arq_editor/file/CRC/IN\%2006-2011.pdf.

Brasil. 2012. Ministério da Agricultura, Pecuária e Abastecimento. Instrução Normativa No. 07, de 04 de abril de 2012. Diário Oficial da União, Brasília, DF, Brazil. Accessed Jul. 5, 2014. http://www. agricultura.gov.br/arq_editor/file/CRC/IN\%2007-2012.pdf.

Brasil. 2013. Ministério da Agricultura, Pecuária e Abastecimento. Instrução Normativa No. 07, de 27 de março de 2013. Diário Oficial da União, Brasília, DF, Brazil. Accessed Jul. 5, 2014. http://www. agricultura.gov.br/arq_editor/file/CRC/IN\%2007-2013.pdf.

Brasil. 2014a. Ministério da Agricultura, Pecuária e Abastecimento. Portaria SDA No. 60, de 07 de maio de 2014. Diário Oficial da União, Brasília, DF, Brazil. Accessed Jul. 5, 2014. http://www. agricultura.gov.br/arq_editor/file/CRC/PORTARIA \%20n\%20 60\%20-\%20PNCRC\%202013.pdf.

Brasil. 2014b. Ministério da Agricultura, Pecuária e Abastecimento. Instrução Normativa No. 11, de 07 de maio de 2014. Diário Oficial da União, Brasília, DF, Brazil. Accessed Jul. 5, 2014. http:// www.agricultura.gov.br/arq_editor/file/CRC/IN\%2011\%20-\%20 PNCRB\%202014.pdf.

Cerkvenik, V., D. Z. Doganoc, V. Skubic, W. M. J. Beek, and H. J. Keukens. 2001. Thermal and long-term freezing stability of ivermectin residues in sheep milk. Eur. Food Res. Technol. 213:72-76.

Cerkvenik, V., B. Perko, I. Rogelj, D. Z. Doganoc, V. Skubic, W. M Beek, and H. J. Keukens. 2004. Fate of IVM residues in ewes' milk and derived products. J. Dairy Res. 71:39-45.

Cerkvenik-Flajs, V., L. Milčinski, A. Süssinger, L. Hodošček, M. Danaher, and J. Antonić. 2010. Trace analysis of endectocides in milk by high performance liquid chromatography with fluorescence detection. Anal. Chim. Acta 663:165-171.

Codex Alimentarius. 2009. Guidelines for the design and implementation of national regulatory food safety assurance programme associated with the use of veterinary drugs in food producing animals. Codex Alimentarius Commission GL 71-2009. Accessed Jun. 10, 2014. http://www.agricultura.gov.br/arq_editor/file/CRC/CACGL\%2071-2009.pdf.

Codex Alimentarius. 2010. Codex standard for butter. Codex Stan A-1-1971. Adopted in 1971. Revision 1999. Last amendment 2010. Accessed Jun. 12, 2014. http://www.codexalimentarius.org/download/standards/170/CXS_279e.pdf.

Danaher, M., L. C. Howells, S. R. H. Crooks, V. Cerkvenik-Flajs, and M. O'Keeffe. 2006. Review of methodology for the determination of macrocyclic lactone residues in biological matrices. J. Chromatogr. B Analyt. Technol. Biomed. Life Sci. 844:175-203.

Danaher, M., W. Radeck, L. Kolar, J. Keegan, and V. CerkvenikFlajs. 2012. Recent developments in the analysis of avermectin and milbemycin residues in food safety and the environment. Curr. Pharm. Biotechnol. 13:936-951.

de França, C. G., M. E. Del Grossi, and V. P. M. de Azevedo Marques. 2009. Censo agropecuário 2006 e a agricultura familiar no Brasil. Ministério do Desenvolvimento Agrário, Brasília, DF, Brazil.

EC (European Commission). 2002. Commission Decision 2002/657/ EC of 12 August 2002 implementing Council Directive 96/23/EC concerning the performance of analytical methods and the interpretation of results. Off. J. Eur. Comm. L221:8-36.

FAO (Food and Agriculture Organization of the United Nations). 2014. Milk production. Accessed Jul. 1, 2014. http://www.fao.org/ agriculture/dairy-gateway/milk-production/en/\#.Uw8_zfldXQg.

Furlani, R. P. Z., F. F. G. Dias, P. M. Nogueira, F. M. L. Gomes, S. A. V. Tfouni, and M. C. R. Camargo. 2014. Occurrence of macrocyclic lactones in milk and yogurt from Brazilian market. Food Contr. 48:43-47.

IBGE (Instituto Brasileiro de Geografia e Estatística). 2010. Pesquisa de Orçamentos Familiares-POF 2008-2009 aquisição alimentar domiciliar per capita. Rio de Janeiro, Brazil. Accessed Jun. 12 , 2014. http://www.ibge.com.br/home/estatistica/populacao/ condicaodevida/pof/2008_2009_aquisicao/pof20082009_aquisicao.pdf.

Imperiale, F. A., M. Busetti, V. Suárez, and C. Lanusse. 2004. Milk excretion of ivermectin and moxidectin in dairy sheep: assessment of drug residues during cheese elaboration and ripening period. J. Agric. Food Chem. 52:6205-6211.

Imperiale, F. A., C. Farias, A. Pis, J. M. Sallovitz, A. Lifschitz, and C. Lanusse. 2009. Thermal stability of antiparasitic macrocyclic lactones milk residues during industrial processing. Food Addit. Contam. A Chem. Anal. Control Expo. Risk Assess. 26:57-62.

Kolberg, D. I. S., M. A. Presta, C. Wickert, M. B. Adaime, and R. Zanella. 2009. Rapid and accurate simultaneous determination of abamectin and ivermectin in bovine milk by high performance liquid chromatography with fluorescence detection. J. Braz. Chem. Soc. 20:1220-1226.

Lobato, V., S. Rath, and F. G. Reyes. 2006. Occurrence of ivermectin in bovine milk from the Brazilian retail market. Food Addit. Contam. 23:668-673.

Macedo, F., E. T. Marsico, C. A. Conte-Júnior, M. F. Resende, T. F. Brasil, and A. D. Pereira Netto. 2015. Development and validation of a method for the determination of low-ppb levels of macrocyclic lactones in butter, using HPLC-fluorescence. Food Chem. 179:239-245. http://dx.doi.org/10.1016/j.foodchem.2015.01.046.

Rübensam, G., F. Barreto, R. B. Hoff, T. L. Kist, and T. M. Pizzolato. 2011. A liquid-liquid extraction procedure followed by a low temperature purification step for the analysis of macrocyclic lactones in milk by liquid chromatography-tandem mass spectrometry and fluorescence detection. Anal. Chim. Acta 705:24-29.

SINDAN (Sindicato Nacional da Indústria de Produtos para Saúde Animal). 2014. Compêndio de Produtos Veterinários. Accessed Jul. 1, 2014. http://www.cpvs.com.br/cpvs/pesquisar.aspx.

Souza, S. S., A. G. Cruz, E. H. M. Walter, J. A. F. Faria, R. M. S. Celeghini, M. M. C. Ferreira, D. Granato, and A. de S. Sant'Ana. 2011. Monitoring the authenticity of Brazilian UHT milk: A chemometric approach. Food Chem. 124:692-695.

Souza, S. V. C., J. A. Lima, J. C. Teodoro, and R. G. Junqueira. 2007. Validação intralaboratorial de método quantitativo para determinação múltipla de resíduos de avermectinas em leite bovino por cromatografia líquida de alta eficiência com detecção de fluorescência. Ciênc. Tecnol. Aliment. 27:823-836.

Spisso, B. F., M. A. Monteiro, M. U. Pereira, R. G. Ferreira, R. P. Costa, T. A. Cruz, and A. W. Nóbrega. 2010. Pilot survey of commercial pasteurized milk consumed in the metropolitan area of Rio de Janeiro, Brazil, for tetracyclines residues, including the 4-epimers of oxytetracycline, tetracycline and chlortetracycline. Food Addit. Contam. B Surveill. 3:220-227. 